\title{
Uncertainty in two-channel infrared remote sensing retrievals of a well-characterised volcanic ash cloud
}

\author{
Luke M. Western ${ }^{1} \cdot$ Matthew I. Watson ${ }^{1} \cdot$ Peter N. Francis $^{2}$
}

Received: 2 September 2014 / Accepted: 18 June 2015 /Published online: 9 July 2015

(C) The Author(s) 2015. This article is published with open access at Springerlink.com

\begin{abstract}
This work provides a sensitivity study of a twochannel passive infrared remote sensing retrieval of effective radius and optical depth using the Spinning Enhanced Visible and Infrared Imager with channels centred at 10.8 and $12.0 \mu \mathrm{m}$ and a look-up table approach to calculate mass column loading. The retrieval is applied to images of two ash clouds from the 2010 Eyjafjallajökull eruption on 6 and 13 May 2010. The 2010 eruption of Eyjafjallajökull is well characterised, especially in terms of the airborne volcanic ash, which allows the relative uncertainties to be investigated within the realms of observation and reasonable approximation. The parameters investigated are as follows: refractive index, surface temperature, cloud top temperature, ash bulk density and, in particular, the uncertainties related to the spread of the ash particle size distribution - in terms of the geometric standard deviation of a lognormal particle size distribution. The lack of constraint on particle size distribution is shown to cause the largest uncertainty in retrieved mass column loading for the 6 May and 13 May ash cloud. A review of measured in situ size distributions of airborne particles is presented with justification for the choice of a lognormal size distribution for the 2010 Eyjafjallajökull eruption.
\end{abstract}

Keywords Hazards · Volcanic ash · Particle size distribution · Remote sensing

Editorial responsibility: J. Taddeucci

Luke M. Western

luke.western@bristol.ac.uk

1 School of Earth Sciences, University of Bristol, Wills Memorial Building, Queen's Road, Bristol BS8 1RJ, UK

2 Met Office, Fitzroy Road, Exeter, Devon EX1 3PB, UK

\section{Introduction}

Damage to aircraft from volcanic ash has been reported since aircraft flight began (Miller and Casadevall 2000). The impact of the 2010 Eyjafjallajökull eruption (Gudmundsson et al. 2012) caused widespread flight cancellations and a conservative revenue loss of US $\$ 1.7$ billion to the airline industry (International Air Transport Association 2010). Since the 2010 Eyjafjallajökull eruption, Iceland, there has been a drive to improve volcanic ash detection and forecasting techniques in order for Volcanic Ash Advisory Centres (VAACs) to issue the relevant advice to aviation authorities.

The London VAAC produces its volcanic ash advisories using a combination of observations and modelling (London Volcanic Ash Advisory Centre 2014). The use of satellite imagery allows the London VAAC to validate and adjust dispersion models qualitatively (Millington et al. 2012) with the potential to perform inversions and assimilation of satellite data to further improve dispersion model accuracy, which are currently areas of research (Pelley et al. in preparation).

This study shows the uncertainties in the retrieved parameters during the 2010 Eyjafjallajökull eruption, namely the effective particle radius and ash cloud optical depth from which the mass column loading can be calculated. The 2010 eruption of Eyjafjallajökull was well observed and measured. Particular emphasis is placed on the uncertainty of in situ measurements of ash particle size distribution and how this uncertainty propagates into remote sensing retrievals. A review of particle size distributions measured via in situ sampling is presented.

\section{Particle size distribution of volcanic ash}

The particle size distribution (PSD) of fine volcanic ash in ash clouds is poorly understood due to the complex fragmentation 
processes that generate fine ash, largely controlled by the composition of the pre-eruptive magma and complex sedimentation processes (Rose and Durant 2009). The PSD in ash clouds is of vital importance in understanding plume dynamics (Mastin et al. 2009) and transport of fine ash (Beckett et al. 2014). The paucity of data on airborne ash PSDs, stemming from the inherent risk involved with sampling airborne ash using manned aircraft, leads to a large uncertainty when applying a PSD to remote sensing retrievals. Currently, there have been no campaigns where an unmanned aerial vehicle has been used to measure airborne PSDs, although this is likely an avenue of future research. Balloons have been used in the past, although no comprehensive PSD measurements have been made using this method (see e.g. Harrison et al. 2010). As a result, assumptions based on limited information often have to be made about the PSD of fine ash.

There is little known about the relationship between particle size and distribution spread of airborne ash size distributions. Standard deviation has been shown to reduce with mean grain size for fall deposits (Dartevelle et al. 2002), and an increase in size range is observed with a decrease in median grain size for total grain size distributions (Rust and Cashman 2011). However, the degree to which ashfall deposits represent an airborne volcanic ash PSD at a given location is unknown, so hereafter, only ash collected from ash 'clouds' is considered to be representative of an airborne ash PSD.

\section{In situ aircraft measurement}

A summary of in situ measurements of size distributions from explosive eruptions made by aircraft is shown in Table 1, and a representative selection of these PSDs can be seen in Fig. 1. The size distributions in Fig. 1 have been truncated to radius values $\leq 12.5 \mu \mathrm{m}$ (the maximum measurable radius by Rose et al. (1980); Rose et al. (1982)) for ease of comparison and normalised such that the maximum value in terms of the number distribution is equal to one. Aircraft sampling of volcanic ash has taken place since the 1960s (Mossop 1964); these samples present variable insight into the form of ash PSDs. Rose et al. (1980) and Rose et al. (1982) sampled PSDs from two Guatemalan volcanoes, Fuego and Santiaguito, and the 1980 Mt. St. Helens eruption. It is difficult to fit these data with a mathematical PSD that is also easy to work with. The difficulty in extracting usable information about PSDs is true for other aircraft measurements made around this period (Chuan et al. 1981, 1986; Hobbs et al. 1977, 1981, 1982, 1991; Woods and Chuan 1982) lasting up until the early 1990s. Few airborne in situ measurements were made after this period (see e.g. Carn et al. 2011) until the 2010 Eyjafjallajökull eruption (e.g. Bukowiecki et al. 2011).

The use of a lognormal PSD to describe volcanic ash PSDs from aircraft measurement appears to have been first suggested by Farlow et al. (1981), from a study in which stratospheric particles from the $1980 \mathrm{Mt}$ St Helens eruption were sampled. Wen and Rose (1994) suggest that the probability density function of the number size distribution of the ash from the 1990 Mt. Redoubt eruption, taken from Hobbs et al. (1991), can be described a lognormal distribution of the form:

$n(r)=\frac{N_{\mathrm{O}}}{\sqrt{2 \pi} r \ln \sigma_{\mathrm{g}}} \exp \left(-\frac{\left(\ln r-\ln r_{\mathrm{g}}\right)^{2}}{2\left(\ln \sigma_{\mathrm{g}}\right)^{2}}\right)$

where $N_{\mathrm{O}}$ is the total number of particles, $r$ is the particle radius, $r_{\mathrm{g}}$ is the geometric mean radius and $\sigma_{\mathrm{g}}$ is the geometric standard deviation. A lognormal distribution has been justified for volcanic ash PSDs for the 2010 Eyjafjallajökull eruption from aircraft measurement (Schumann et al. 2011; Johnson et al. 2012; Turnbull et al. 2012). Although all flights where the ash PSD was measured were during the same eruptive phase, discrepancies exist between PSD parameter measurements, perhaps due to the difference in assumed ash properties and sampling methods used (see Turnbull et al. (2012) for full discussion). It must also be noted that these flights were not necessarily through areas of high ash concentrations and may therefore only be representative of the PSD found at the peripheries of the ash cloud. Where higher concentrations were sampled, it was generally relative to mass loading of clouds at considerable distance downwind (Prata and Prata 2012). The parameters describing monomodal lognormal ash PSDs measured from aircraft-collected samples are described in Table 2 . It has been suggested (Stevenson et al. 2015) that failures in detection of large particles, as opposed to an absence, may have been an issue during past airborne in situ measurements, and the potential shortcomings and misrepresentation of aircraft PSD measurements are discussed.

\section{Passive infrared remote sensing of volcanic ash}

Here, a brief introduction to passive infrared remote sensing retrieval algorithms is presented. Although only a two-channel remote sensing algorithm is used in this work to retrieve ash cloud properties and quantify uncertainty, selected retrieval algorithms are presented for completeness.

Detection of volcanic ash using infrared remote sensing has generally evolved from a two-channel technique using brightness temperature difference (Prata 1989a, b). This technique uses infrared channels centred around wavelengths 10.8 and $12.0 \mu \mathrm{m}$ in an atmospheric window. The brightness temperature difference of these channels, brightness temperature difference $\mathrm{BTD}=\mathrm{BT}_{10.8}-\mathrm{BT}_{12.0}$, generally gives a negative $\mathrm{BTD}$ for pixels containing volcanic ash and a positive BTD for meteorological cloud. This allows identification of those pixels containing volcanic ash from remotely sensed satellite images. Shortcomings of this technique, e.g. a negative brightness temperature over clear desert surfaces, have been discussed in previous literature (Simpson 2000; Prata et al. 2001). 
Table 1 Summary of airborne in situ measurements of ash particle size distributions from 1963 to 2010

\begin{tabular}{|c|c|c|c|}
\hline Volcano & Date & Distance from source & Source \\
\hline El Chichón & April-Nov 1982 & Varied & Gooding et al. (1983) \\
\hline El Chichón & Dec-Jan 1983 & Distal & Knollenberg and Huffman (1983) \\
\hline Eyjafjallajökull & April-May 2010 & Distal & Johnson et al. (2012) \\
\hline Eyjafjallajökull & 17 May 2010 & Distal & Turnbull et al. (2012) \\
\hline Eyjafjallajökull & April-May 2010 & Distal & Schumann et al. (2011) \\
\hline Eyjafjallajökull & April-May 2010 & Distal & Bukowiecki et al. (2011) \\
\hline Fuego & Feb 1978 & $\leq 27.5 \mathrm{~km}$ & Cadle et al. (1979); Rose et al. (1980) \\
\hline Mt. Agung & April 1963-April 1964 & Varied & Mossop (1964) \\
\hline Mt. Erebus & 9 Dec 1983 & $\leq 13.5 \mathrm{~km}$ & Chuan et al. (1986) \\
\hline Mt. Redoubt & Jan 1990 & $20-170 \mathrm{~km}$ & Hobbs et al. (1991) \\
\hline Mt. St. Helens & March-May 1980 & $3-130 \mathrm{~km}$ & Hobbs et al. (1981) \\
\hline Mt. St. Helens & March-May 1980 & 4- $453 \mathrm{~km}$ & Hobbs et al. (1982) \\
\hline Mt. St. Helens & April-Aug 1980 & & Chuan et al. (1981) \\
\hline Mt. St. Helens & May-June 1980 & & Farlow et al. (1981) \\
\hline Mt. St. Helens & June-Aug 1980 & & Rose et al. (1982) \\
\hline Mt. St. Helens & 21 May 1980 & & Deepak et al. (1982) \\
\hline Pinatubo & Feb 1991-March 1992 & Distal & Pueschel et al. (1994) \\
\hline St. Augustine & 8 Feb 1976 & $30 \mathrm{~km}, 70 \mathrm{~km}$ & Hobbs et al. (1977) \\
\hline Santiaguito & Feb 1978 & $\leq 29 \mathrm{~km}$ & Cadle et al. (1979); Rose et al. (1980) \\
\hline Soufrière Hills & April-May 1979 & $\geq 45 \mathrm{~km}$ & Woods and Chuan (1982) \\
\hline Tungurahua (likely) & 17, 29 July 2007 & $\sim 500-550 \mathrm{~km}$ & Carn et al. (2011) \\
\hline
\end{tabular}

The use of passive infrared remote sensing to retrieve physical properties of volcanic ash clouds was first proposed by Wen and Rose (1994). This approach uses the aforementioned $\mathrm{BTD}$, along with $\mathrm{BT}_{10.8}$, to retrieve cloud particle size and optical depth using a look-up table precalculated via radiative transfer theory. From this, an estimate of cloud mass loading can be made. This work was improved upon in later retrieval algorithms by utilizing further spectral channels (Prata and Grant 2001a) and the introduction of new radiative parameter apart from brightness temperature (Pavolonis 2010). Optimal estimation has proved a useful tool for the retrieval of ash microphysical properties, where the retrieval scheme attempts to reach a statistically optimal estimate of the properties of the ash cloud consistent with any a priori knowledge of the background state. A method to retrieve volcanic cloud height, effective radius and mass column loading was developed by Francis et al. (2012). The retrieval uses channels with central wavelengths of $10.8,12.0$ and $13.4 \mu \mathrm{m}$. The retrieval scheme attempts to reach a statistically optimal estimate of the properties of the ash cloud consistent with any a priori knowledge of the background state and any available information from observation. This method does not retrieve the shape of the PSD of the ash cloud as an element of the state vector, but a range of $\sigma_{\mathrm{g}}$ values for a lognormal distribution from 1.25 to 3.0 is used in order to find the least cost solution during the retrieval. In a method similar to the above, Pavolonis et al. (2013) exploit the effective absorption optical depth ratio and effective cloud emissivity in its methodology, using wavelengths centred around 10.8, 12.0 and $13.3 \mu \mathrm{m}$. Assumptions about the composition of the ash are made, for which three refractive indices data sets are tested, and an assumption about the ash PSD has to be made. Similar to other retrieval methods, a lognormal distribution is used with a fixed geometric standard deviation. Clarisse et al. (2010) demonstrated an alternate method of optimal estimation using the Infrared Atmospheric Sounding Interferometer (IASI) (Clerbaux et al. 2009). This method takes advantage of IASI's high spectral resolution in the range $800-1200 \mathrm{~cm}^{-1}$ (8.3-12.5 $\mu \mathrm{m})$, but again, an assumption of the ash composition and PSD is needed. A lognormal PSD with a fixed geometric standard deviation is used for this retrieval.

Wen and Rose (1994) highlight the sensitivity of ash detection and subsequent retrieval due to the refractive index of ash chosen, an issue that has been raised in subsequent papers (Francis et al. 2012; Mackie et al. 2014). It is stated that the uncertainty attributed to PSD has a greater effect on retrievals than uncertainty in refractive index (Wen and Rose 1994). A detailed sensitivity analysis has been carried out by Corradini et al. (2008) who investigate retrieval uncertainties in the surface temperature and emissivity, plume geometry, ash 

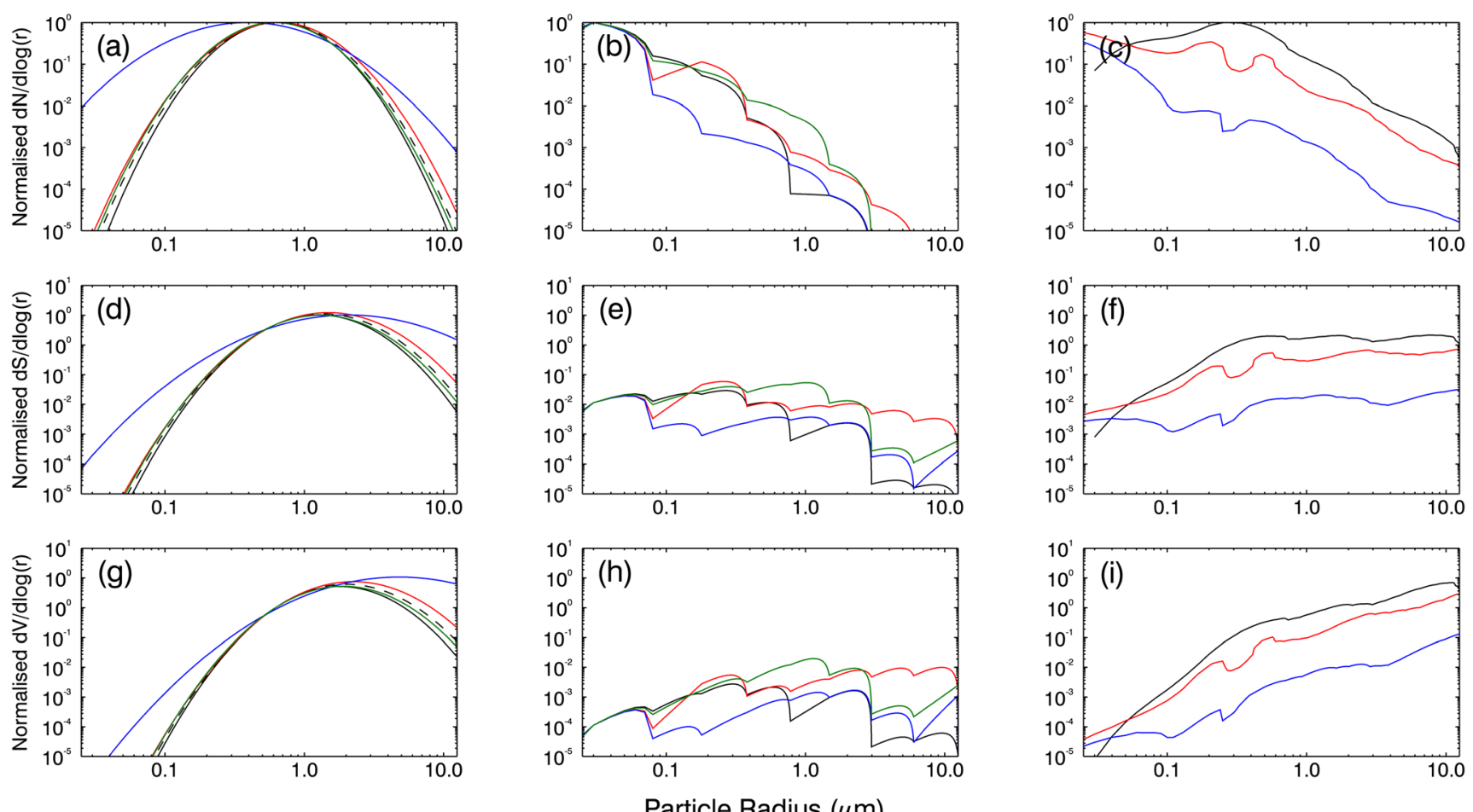

Particle Radius $(\mu \mathrm{m})$

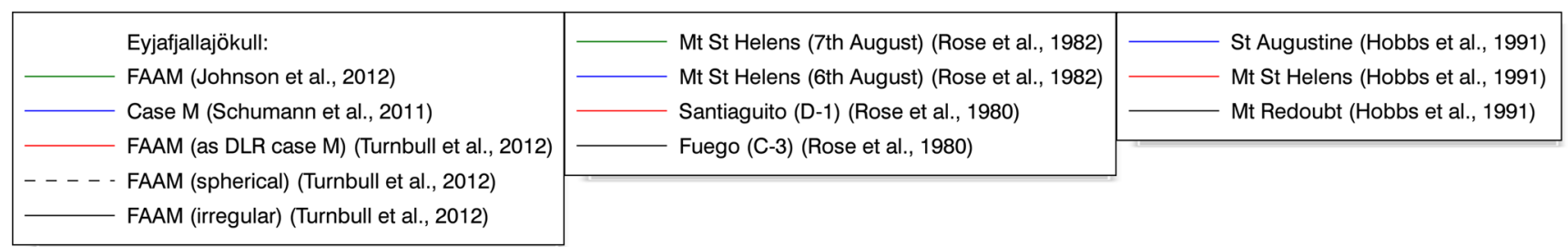

Fig. 1 Examples of in situ aircraft measurements of ash PSDs in terms of number $(\mathbf{a}-\mathbf{c})$, surface $(\mathbf{d}-\mathbf{f})$ and volume $(\mathbf{g}-\mathbf{i})$ distribution. All distributions are truncated to radius values $\leq 12.5 \mu \mathrm{m}$ (the maximum measureable radius by Rose et al. (1982); Rose et al. (1980)) and normalised such that the maximum value in terms of $\frac{d N}{d \log N}$ equals one. FAAM Facility for Airborne Atmospheric Measurement
Table 2 Summary of airborne in situ measurements of lognormal ash particle size distribution with values for geometric standard deviation, $\sigma_{\mathrm{g}}$, and geometric mean radius, $r_{\mathrm{g}}$, given for particles distributed by their number distribution, as Eq. (1)

\begin{tabular}{lllll}
\hline Volcano & Date & $\sigma_{\mathrm{g}}$ & $r_{\mathrm{g}}(\mu \mathrm{m})$ & Source \\
\hline Eyjafjallajökull & $\begin{array}{c}\text { April- } \\
\text { May 2010 }\end{array}$ & $1.85 \pm 0.05$ & 0.610 & Johnson et al. (2012) \\
Eyjafjallajökull $^{\mathrm{b}}$ & 17 May 2010 & 1.80 & 0.638 & Turnbull et al. (2012) (irregular) \\
Eyjafjallajökull $^{\mathrm{b}}$ & 17 May 2010 & 1.85 & 0.643 & Turnbull et al. (2012) (spheres) \\
Eyjafjallajökull $^{\mathrm{b}}$ & 17 May 2010 & 1.9 & 0.654 & Turnbull et al. (2012) (as DLR Case M) \\
Eyjafjallajökull $^{\text {17 May 2010 }}$ & 2.5 & 0.387 & Schumann et al. (2011) (Case M) \\
Mt. Redoubt $^{\mathrm{a}}$ & 8 January 1990 & 2.10 & 0.8 & Hobbs et al. (1991) \\
Mt. St. Helens & 22 May 1980 & 1.71 & 0.476 & Farlow et al. (1981) \\
Mt. St. Helens & 27 May 1980 & 1.74 & 0.478 & Farlow et al. (1981) \\
Mt. St. Helens & 29 May 1980 & 1.60 & 0.702 & Farlow et al. (1981) \\
Mt. St. Helens & 3 June 1980 & 1.72 & 0.942 & Farlow et al. (1981) \\
Mt. St. Helens & 13 June 1980 & 1.53 & 0.777 & Farlow et al. (1981) \\
\hline
\end{tabular}

$D L R$ Deutsches Zentrum für Luft- und Raumfahrt

${ }^{a}$ Mt. Redoubt parameters as given by Wen and Rose (1994)

${ }^{\mathrm{b}}$ Same measurement using different single scattering properties 
refractive index and atmospheric water vapour. At present, there has been no quantitative sensitivity study on the effect of an unknown geometric standard deviation value when the size distribution is known to be lognormal. This paper presents a sensitivity study of the parameters of an ash cloud from the well-characterised 2010 Eyjafjallajökull eruption using a two-channel passive infrared retrieval scheme.

\section{Method}

A two-channel infrared retrieval, in the style of Wen and Rose (1994), has been used to investigate the sensitivity of effective radius and optical depth retrieval, and subsequent mass loading calculation, of an ash cloud to surface and cloud top temperature, refractive index, ash bulk density and geometric standard deviation of a lognormal PSD.

This method uses the Spinning Enhanced Visible and Infrared Imager (SEVIRI) on-board the Meteosat Second Generation (MSG) geostationary observational satellite. The SEVIRI instrument is a centred at $0^{\circ}$ longitude with 12 spectral channels, the two being used here centred at 10.8 and $12.0 \mu \mathrm{m}$, with an equatorial spatial resolution of $3 \mathrm{~km}$ for its infrared channels. SEVIRI has a baseline repeat cycle of $15 \mathrm{~min}$, which made it a vital observation source during the 2010 Eyjafjallajökull eruption.

Initially, pixels containing ash are identified using a BTD threshold $\mathrm{BTD}<-1.5 \mathrm{~K}$. This method is likely to detect some pixels as false positives for ash and fail to detect many more. A more negative BTD value does not necessarily suggest that more ash is present, and therefore, both optically thin and opaque clouds could fail to be identified. This identification scheme proves adequate for the task of a sensitivity study.

The retrieval of properties of the ash cloud stems from the radiative transfer model proposed by Prata (1989a), where the observed radiance from an ash cloud can be approximated by the following:

$I=(1-\varepsilon) B\left(T_{s}\right)+\varepsilon B\left(T_{c}\right)$

where $T_{\mathrm{s}}$ is the temperature of the surface, $T_{\mathrm{c}}$ is the temperature of the cloud top, $B$ is the Planck function and $\varepsilon$ is the spectral emissivity at satellite zenith angle given by the following:

$\varepsilon=1-\exp \left(-\frac{\tau}{\cos \theta}\right)$

The optical depth $\tau$ at wavelength $\lambda$ can be calculated by the following:

$\tau=\pi L \int_{o}^{\infty} r^{2} Q_{\mathrm{ext}} n(r) d r$

where $L$ is the geometric thickness of a homogeneous cloud and $Q_{\text {ext }}$ is the extinction efficiency factor of a single particle.
The extinction efficiency factor of a distribution of particles $\tilde{Q}_{\text {ext }}$ can be expressed as follows:

$\tilde{Q}_{\mathrm{ext}}=\frac{\int_{o}^{\infty} r^{2} Q_{\mathrm{ext}} n(r) d r}{\int_{0}^{\infty} r^{2} n(r) d r}$

The effective radius of the distribution $r_{\mathrm{e}}$ is defined by the following:

$r_{\mathrm{e}}=\frac{\int_{o}^{\infty} r^{3} n(r) d r}{\int_{o}^{\infty} r^{2} n(r) d r}$

Given a lognormal size distribution, this will then simplify to give the following:

$r_{\mathrm{e}}=r_{\mathrm{g}} \exp \left(\frac{5}{2}\left(\operatorname{In} \sigma_{\mathrm{g}}\right)^{2}\right)$

It is then assumed that particles of size $r_{\mathrm{e}}$ are distributed uniformly throughout a homogeneous cloud from which the mass column loading can be found by the following:

$m_{l}=\frac{4}{3} \rho r_{\mathrm{e}} \frac{\tau}{\tilde{Q}_{\mathrm{ext}}}$

where $\rho$ is the bulk density of the ash.

A Mie scattering routine (Bohren and Huffman 1983) is used to forward model the single scattering properties of the ash particles. By calculating observed brightness temperatures using Eq. (3), a look-up table can be used to forward model the brightness temperature at a wavelength of $10.8 \mu \mathrm{m}$ and BTD values for a planar homogenous ash cloud of different optical depths at $10.8 \mu \mathrm{m}$ for different effective radii. The optical depth of the ash cloud at a wavelength of $10.8 \mu \mathrm{m}$ is found by matching the brightness temperature at $10.8 \mu \mathrm{m}, \mathrm{BT}_{10.8}$, to the values forward modelled in the look-up table. The extinction efficiency factor and effective radius are found by comparing the observed BTD to the forward modelled values at this given optical depth. In the retrieval scheme presented by Wen and Rose (1994), the cloud top temperature, $T_{\mathrm{C}}$, is assigned as the coldest $\mathrm{BT}_{10.8}$ where ash pixels have been identified, and the surface temperature, $T_{\mathrm{S}}$, is found by analysis of ash-free pixels close to the volcanic ash cloud. Rather than relying on the image to determine surface temperature, $T_{\mathrm{S}}$, as Wen and Rose (1994), it has been taken from the European Centre for Medium-Range Weather Forecasts' (ECMWF) Global Reanalysis data set (Dee et al. 2011) using the previous time step before the SEVIRI image was acquired. The mean skin temperature for an area roughly encompassing the ash cloud has been selected as a value for $T_{\mathrm{S}}$, and an 
uncertainty of one standard deviation $\left(\sigma_{T \mathrm{~S}}\right)$ is used as a perturbation. A sea surface emissivity of 0.99 is assumed throughout (Sherlock 1999).

Wen and Rose (1994) neglect the satellite zenith angle during their retrieval. Given that SEVIRI is a geostationary satellite, the retrieval scheme employed here provides separate forward modelled radiance values for each satellite zenith angle at $1^{\circ}$ intervals. Further to this, a semi-empirical water vapour correction is applied to BTD on a pixel-by-pixel basis (Prata and Grant 2001b) with a typical value of approximately $0.5 \mathrm{~K}$, which will vary dependent on the optical depth at $10.8 \mu \mathrm{m}$, and, therefore, the extent of water vapour encountered, for each pixel. This correction is needed, as Eq. 2 does not account for atmospheric extinction due to water vapour.

\section{Case study: 2010 Eyjafjallajökull eruption}

The 2010 Eyjafjallajökull eruption was a complex eruption, with changes in magmatic composition and eruptive style, lasting 39 days during April-May (Gudmundsson et al. 2012; Spinetti et al. 2013). Although the eruption was somewhat atypical, it has been extensively studied through in situ observations and post-eruptive analysis. This has allowed the parameters governing remote sensing retrievals to be reasonably well characterised. This study aims to understand the uncertainties in infrared passive remote sensing retrievals when particle distribution in an ash cloud is well constrained and compare that to information usually available during realtime monitoring, using available data published in literature as a best approximation.

The cloud top temperature, $T_{\mathrm{C}}$, is difficult to constrain, even with observations, due to the variability in atmospheric pressure in space and time. The value for $T_{\mathrm{C}}$ is taken from the image itself, as the coldest $\mathrm{BT}_{10.8}$ where ash has been identified, as Wen and Rose (1994), and is likely to be an overestimation of the cloud top temperature. This is because the top of the ash cloud is unlikely to be opaque and thus be an underestimation of cloud top altitude. The average variation in cloud height measured by scientists on 6 flights during the eruption, using airborne lidar from the UK Facility for Airborne Atmospheric Measurements (FAAM), was roughly $2.5 \mathrm{~km}$ (Marenco et al. 2011) and $2.1 \mathrm{~km}$ from 11 flights by the Deutsches Zentrum für Luft- und Raumfahrt (DLR) (Schumann et al. 2011). The cloud is therefore perturbed to an altitude roughly $2.5 \mathrm{~km}$ higher, with the corresponding cloud top temperature taken from an atmospheric profile from the ECMWF Global Reanalysis data. The cloud is perturbed to a higher altitude, as the retrieved cloud top temperature from the image itself is likely to be an underestimation of cloud top height, and the upper cloud top variation through observation is used. A value for the bulk density of very fine ash has been given by Bonadonna et al. (2011) for the eruptive activity from the 4-10 May as $=2738 \mathrm{~kg} \mathrm{~m}^{-3}$; the London VAAC used a value of $2300 \mathrm{~kg} \mathrm{~m}^{-3}$ as a best approximation to volcanic ash density from Eyjafjallajökull (Bonadonna and Phillips 2003). The refractive indices of a tephra sample from the Eyjafjallajökull eruption collected on 17 April 2010 have been measured at the University of Oxford (Dan Peters, personal communication). The composition of ash was shown to change over the course of the eruption (Gudmundsson et al. 2012), and therefore, other reasonable approximations of a suitable refractive index could be that of andesite (Pollack et al. 1973) and volcanic pumice (Volz 1973). The PSD of the volcanic ash was observed to be lognormal during in situ sampling at various dates throughout April and May by the FAAM (Johnson et al. 2012) and DLR (Schumann et al. 2011) aircrafts, and therefore, a lognormal PSD is used. The average value for the geometric standard deviation given by Johnson et al. $2012\left(\sigma_{\mathrm{g}}=1.85 \pm 0.5\right.$, dependent on assumed single scattering properties) is here considered the best approximation to use. Variations in atmospheric water vapour, surface emissivity and plume geometry are not discussed, but this work is well covered by Corradini et al. (2008).

Two separate SEVIRI images from the main explosive phase of the 2010 Eyjafjallajökull eruption are investigated here - the first on 6 May 2010 at 1900 UTC and the second on 13 May 2010 at 0800 UTC.

\section{Sensitivity study: results and discussion}

Table 3 details the retrieval parameters that are kept constant and perturbed to in the retrieval method. The retrieved mass column loadings, effective radii and optical depths using the constant parameters detailed in Table 3 are shown in Fig. 2 for 6 May 2010 at 1900 UTC and 13 May 2010 at 0800 UTC. The relative uncertainty of the retrieval for both ash clouds for a change in $\sigma_{\mathrm{g}}$ of the PSD and refractive index with respect to the mass column loading and effective radius can be seen in Fig. 3. The retrieval uncertainty of mass column loading, effective radius and optical depth caused by an uncertainty in surface and cloud top temperature can be seen in Fig. 4. The uncertainties are summarised in Table 4 in terms of percentage bias. Bias is defined as (Mosca et al. 1998):

Bias $=\frac{1}{N} \sum_{i=1}^{N}\left(x_{i}-x_{i}^{\prime}\right)$

Here, $N$ is the number of pixels, $x_{i}$ is the retrieved or calculated quantity for a given pixel using the constant parameter values, and $x_{i}^{\prime}$ is the retrieved or calculated quantity for a given pixel using the perturbed parameter values in Table 3 . Therefore, a negative bias corresponds to an overall reduction in the retrieved quantity and a positive bias corresponds to an 
Table 3 Constant parameter and perturbed parameter values assumed for an ash cloud from the Eyjafjallajökull eruption on 6 May 20101900 UTC and 13 May 20100800 UTC

\begin{tabular}{|c|c|c|c|}
\hline Parameter & Constant value & Perturbation & Source \\
\hline Geometric standard deviation & 1.85 & $\begin{array}{l}1.8 \\
2.5\end{array}$ & $\begin{array}{l}\text { Johnson et al. (2012) } \\
\text { Schumann et al. (2011) }\end{array}$ \\
\hline Refractive index & Eyjafjallajökull ash & $\begin{array}{l}\text { Andesite } \\
\text { Volcanic pumice }\end{array}$ & $\begin{array}{l}\text { Dan Peters, personal communication } \\
\text { Pollack et al. (1973) } \\
\text { Volz (1973) }\end{array}$ \\
\hline Bulk density & $2738 \mathrm{~kg} \mathrm{~m}^{-3}$ & $2300 \mathrm{~kg} \mathrm{~m}^{-3}$ & $\begin{array}{l}\text { Bonadonna et al. (2011) } \\
\text { Bonadonna and Phillips (2003) }\end{array}$ \\
\hline Cloud top temperature & $\begin{array}{l}\text { 6 May } 20101900 \text { UTC } \\
228.50 \mathrm{~K} \\
13 \text { May } 20100800 \mathrm{UTC} \\
238.00 \mathrm{~K}\end{array}$ & $\begin{array}{l}6 \text { May } 20101900 \mathrm{UTC} \\
219.62 \mathrm{~K}(+\sim 2.5 \mathrm{~km}) \\
13 \text { May } 20100800 \mathrm{UTC} \\
226.54 \mathrm{~K}(+\sim 2.5 \mathrm{~km})\end{array}$ & Marenco et al. (2011) \\
\hline Surface temperature & $\begin{array}{l}6 \text { May } 20101900 \text { UTC } \\
282.79 \mathrm{~K} \\
13 \text { May } 20100800 \mathrm{UTC} \\
278.64 \mathrm{~K}\end{array}$ & $\begin{array}{l}6 \text { May } 20101900 \mathrm{UTC} \\
283.60 \mathrm{~K}\left(+1 \sigma_{T \mathrm{~s}}\right) \\
281.98 \mathrm{~K}\left(-1 \sigma_{T \mathrm{~s}}\right) \\
13 \text { May } 20100800 \mathrm{UTC} \\
281.58 \mathrm{~K}\left(+1 \sigma_{T \mathrm{~s}}\right) \\
275.70 \mathrm{~K}\left(-1 \sigma_{T \mathrm{~s}}\right)\end{array}$ & $\begin{array}{l}\text { ECMWF Global Reanalysis data set } \\
\text { (Dee et al. 2011) }\end{array}$ \\
\hline
\end{tabular}
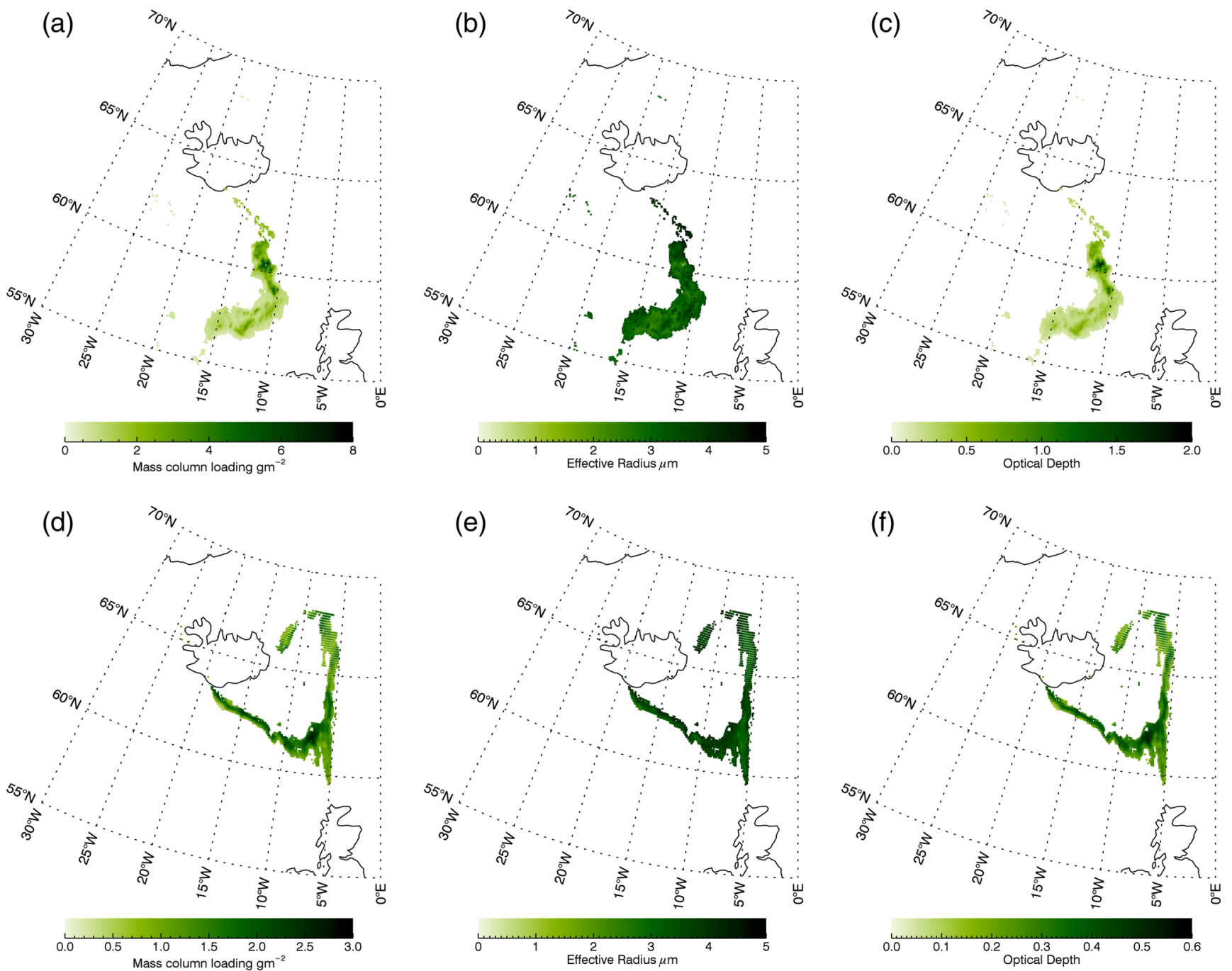

Fig. 2 Retrieval of mass column loading, effective radius and optical depth from a SEVIRI image on 6 May 20101900 UTC (a-c) and 13 May 2010 0800 UTC (d-f) 
Mass Column Loading
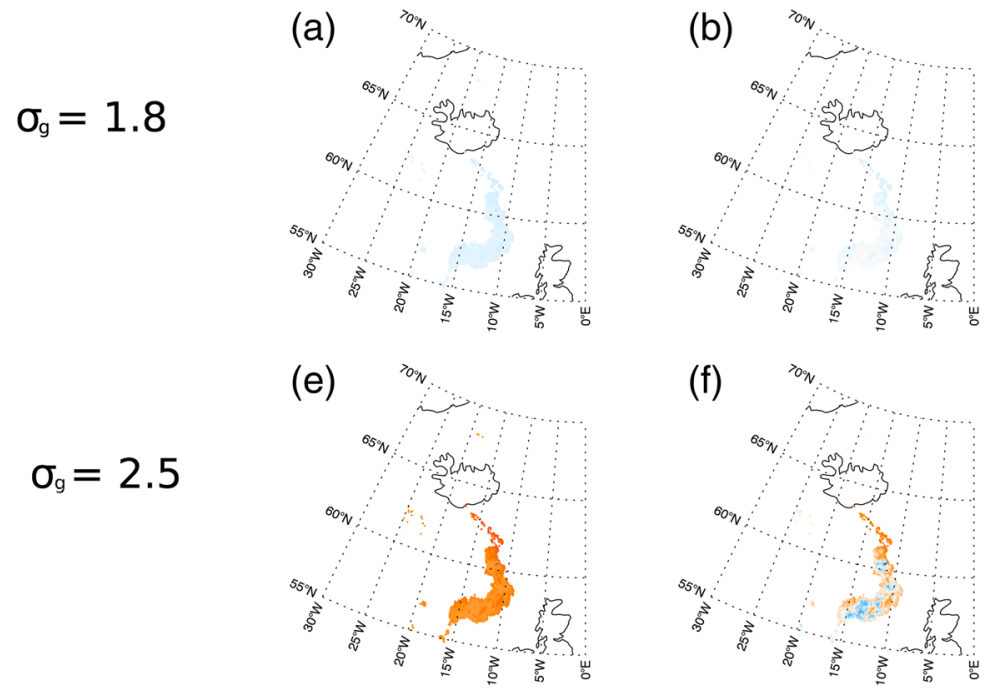

$$
\sigma_{9}=2.5
$$

\section{Andesite}
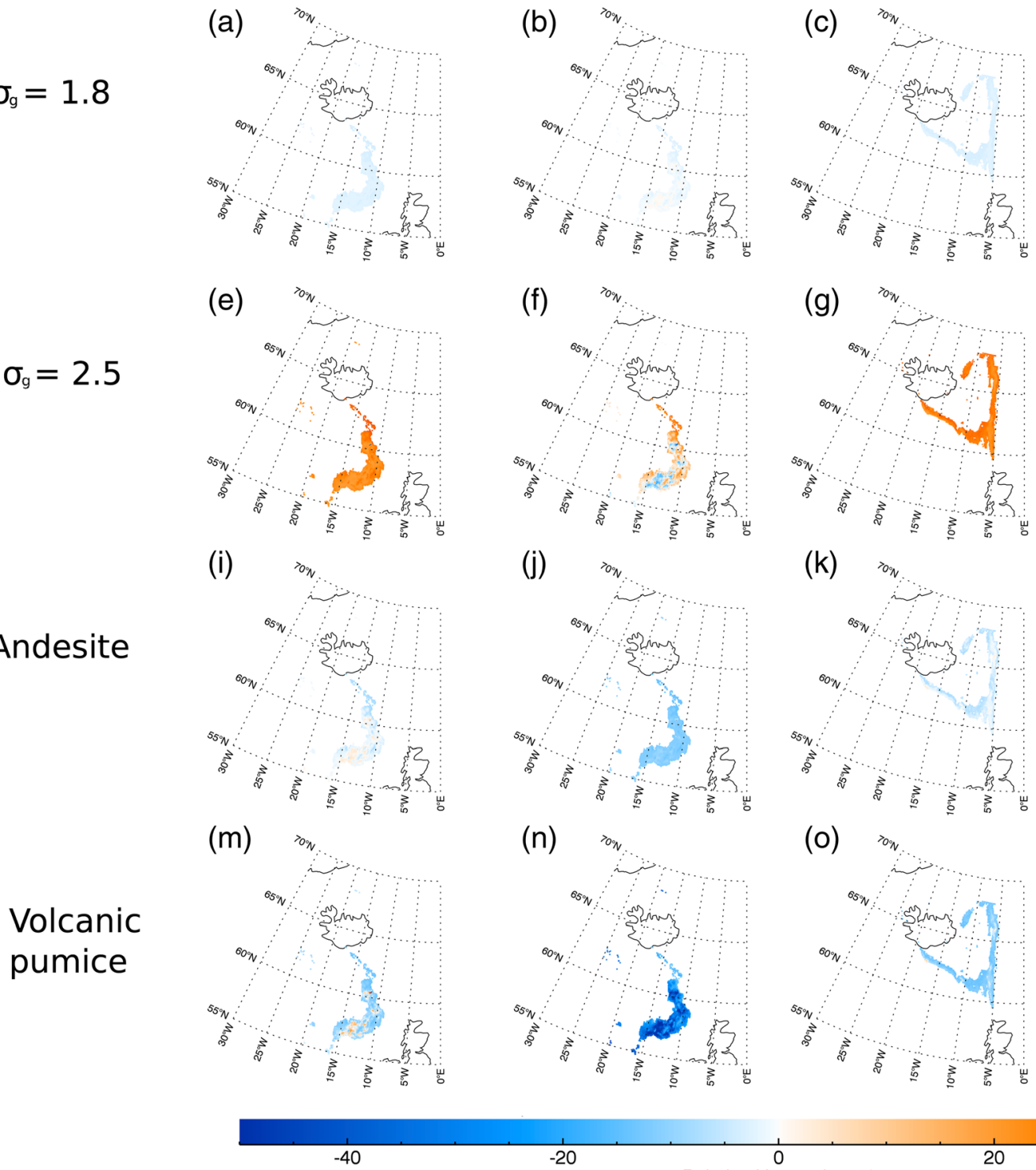

Effective Radius
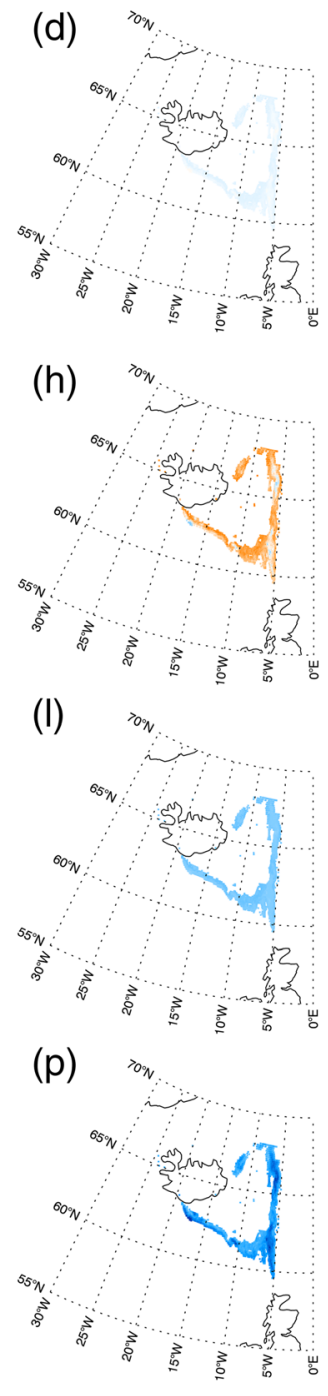

$-40$

Fig. 3 Relative uncertainty of retrieved mass column loading and effective radius with respect to the constant parameters detailed in Table 3 for a SEVIRI image on 6 May 20101900 UTC (left) and 13

overall increase in the retrieved quantity. The uncertainty caused by an uncertain ash bulk density is not displayed, as this will be a simple factor of $16 \%$ reduction in mass when a density of $2300 \mathrm{~kg} \mathrm{~m}^{-3}$ is used with retrievals of effective radius and optical depth unaffected.

\section{Discussion}

The effect of an uncertain refractive index on ash cloud retrievals has been discussed in previous literature (Francis et al. 2012; Wen and Rose 1994). Retrieval of real-time refractive indices is currently not an option, and
Relative Uncertainty \%

40

May 20100800 UTC (right) with a perturbation of as follows: $\sigma_{\mathrm{g}}=1.8$ $(\mathbf{a}-\mathbf{d}), \sigma_{\mathrm{g}}=2.5(\mathbf{e}-\mathbf{h})$, andesite $(\mathbf{i}-\mathbf{l})$ and volcanic pumice $(\mathbf{m}-\mathbf{p})$

therefore, some assumption will have to be made here. In the case of the 2010 Eyjafjallajökull eruption, composition was shown to change with time (Gudmundsson et al. 2012), suggesting that even if a rapid laboratory determination of refractive index was possible, uncertainties are likely to emerge. For similar reasons, the density of very fine ash is difficult to constrain and is likely to change with compositional changes. Therefore, estimates have to be made from available literature sources (e.g. Bonadonna and Phillips 2003). A change in the $\sigma_{\mathrm{g}}$ of the PSD is shown to have a significant effect on mass loading retrievals with a bias between -3.7 and $51.5 \%$. Reasons for this 

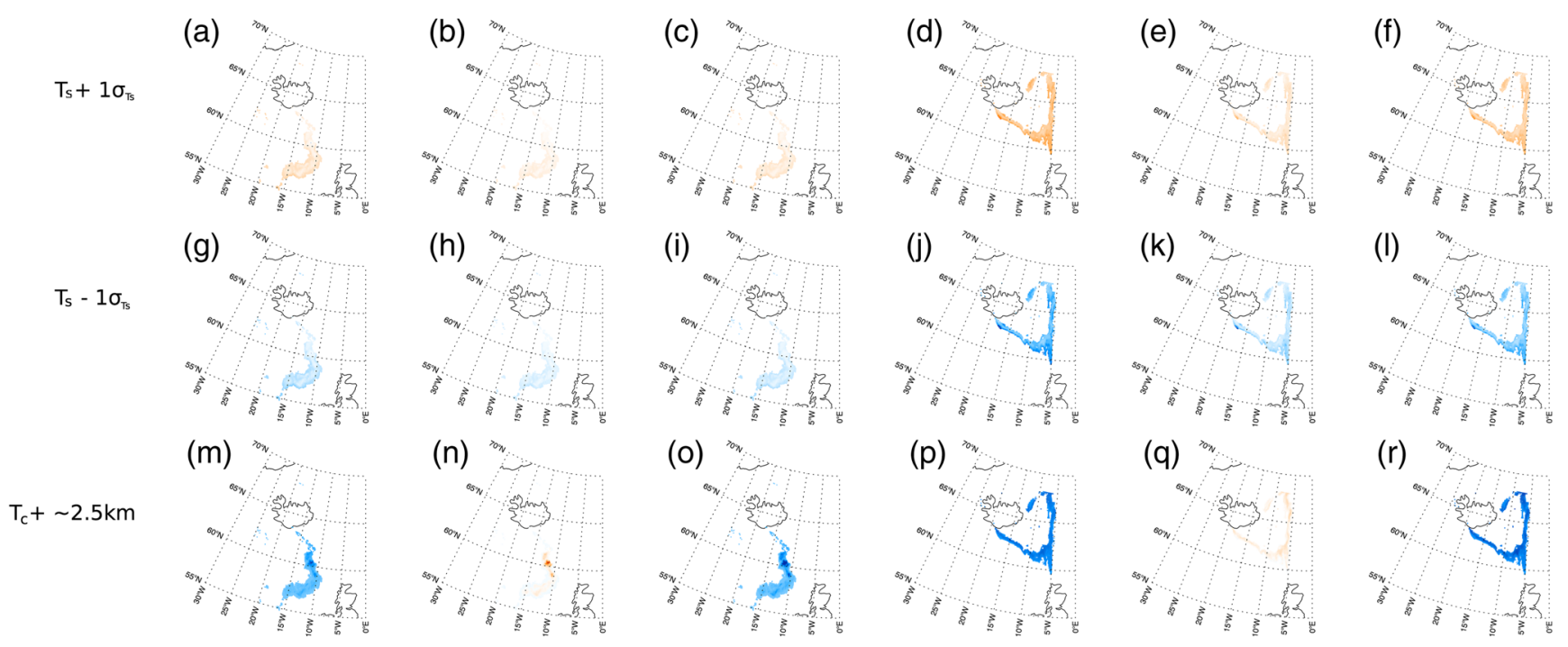

\section{(r)}

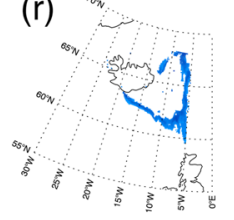

Fig. 4 Relative uncertainty of retrieved mass column loading, effective radius and optical depth with respect to the constant parameters detailed in Table 3 for a SEVIRI image on 6 May 20101900 UTC (left three

uncertainty are described in more detail later in this paper in "Reasons for retrieval uncertainties from size distribution" section. The PSD of the fine ash from an eruption is rarely constrained and, unlike refractive indices and density, is unlikely to be estimated using eruptive history or rapid petrological analysis. The spatial, temporal and compositional variation of an ash cloud's PSD is unknown and is likely to cause significant uncertainty, especially where even the form of the PSD is unknown. These uncertainties are likely to propagate into other retrieval schemes where assumptions of PSD are made (e.g. Francis et al. 2012; Pavolonis et al. 2013).

Cloud top temperature is again difficult to constrain via observation and has a large uncertainty associated with it.
Relative Uncertainty \%

columns) and 13 May 20100800 UTC (right three columns) with a perturbation of as follows: $T_{\mathrm{S}}+1 \sigma_{T \mathrm{~s}}(\mathbf{a}-\mathbf{f}), T_{\mathrm{S}}-1 \sigma_{T \mathrm{~s}}(\mathbf{g}-\mathbf{l})$ and $T_{\mathrm{C}}+$ $\sim 2.5 \mathrm{~km}(\mathbf{m}-\mathbf{r})$

It is highly unlikely that the ash cloud itself will be at a constant altitude, or indeed, the cloud top temperature estimated from the SEVIRI image is correct. Determination of $T_{\mathrm{C}}$ from the image could cause an underestimation of the mass of lower altitude volcanic ash and an overestimation of the highest part of the ash cloud. Information from space-borne lidar such as CALIOP (Winker et al. 2009) is sometimes available, which helps to constrain ash cloud height and geometric thickness along a given path, however may not be relevant for the full spatial extent of the ash cloud. Uncertainty from surface temperature is shown to vary with the conditions underlying the ash cloud due to the increase in surface temperature variability underlying the higher latitude ash cloud on 13 May 2010. The
Table 4 The retrieval percentage bias for the perturbed parameters from the constant parameters shown in Table 3 for an ash cloud from the Eyjafjallajökull eruption on 6 May 20101900 UTC and 13 May 20100800 UTC

\begin{tabular}{|c|c|c|c|c|c|c|}
\hline \multirow[t]{2}{*}{ Perturbation } & \multicolumn{3}{|c|}{6 May 2010} & \multicolumn{3}{|c|}{13 May 2010} \\
\hline & $\begin{array}{l}\text { Mass } \\
\text { loading }\end{array}$ & $\begin{array}{l}\text { Effective } \\
\text { radius }\end{array}$ & $\begin{array}{l}\text { Optical } \\
\text { depth }\end{array}$ & $\begin{array}{l}\text { Mass } \\
\text { loading }\end{array}$ & $\begin{array}{l}\text { Effective } \\
\text { radius }\end{array}$ & $\begin{array}{l}\text { Optica } \\
\text { depth }\end{array}$ \\
\hline$\sigma_{\mathrm{g}}=1.8$ & -3.2 & -1.9 & & -3.7 & -4.6 & \\
\hline$\sigma_{\mathrm{g}}=2.5$ & 44.7 & 21.6 & & 51.5 & 57.1 & \\
\hline Andesite & -1.9 & -31.5 & & -5.0 & -38.1 & \\
\hline Volcanic pumice & -9.6 & -74.2 & & -14.1 & -66.6 & \\
\hline$T_{\mathrm{S}}+1 \sigma_{T \mathrm{~s}}$ & 4.7 & 5.1 & 0.8 & 17.8 & 14.7 & 2.8 \\
\hline$T_{\mathrm{S}}-1 \sigma_{T \mathrm{~s}}$ & -4.6 & -5.5 & -0.8 & -18.7 & -18.9 & -3.0 \\
\hline$T_{\mathrm{C}}+\sim 2.5 \mathrm{~km}$ & -21.3 & 5.5 & -5.8 & -32.8 & 8.1 & -7.5 \\
\hline
\end{tabular}

The optical depth indicates the retrieved optical depth at a wavelength of $10.8 \mu \mathrm{m}$ 
Fig. 5 Mass extinction coefficients calculated for spherical particles using the refractive indices of ash from the Eyjafjallajökull eruption at 10.8 (a) and $12.0 \mu \mathrm{m}$ (b) as a function of effective radius. A lognormal size distribution is used with a differing geometric standard deviation of $\sigma_{\mathrm{g}}=1.5,2.0$ and 2.5 (a)

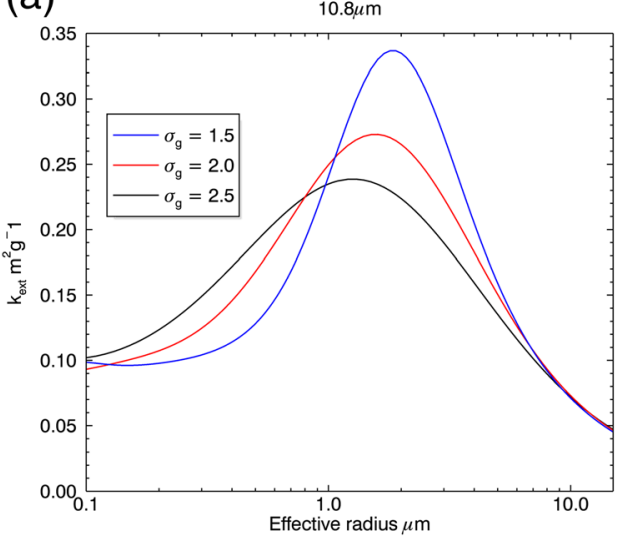

(b)

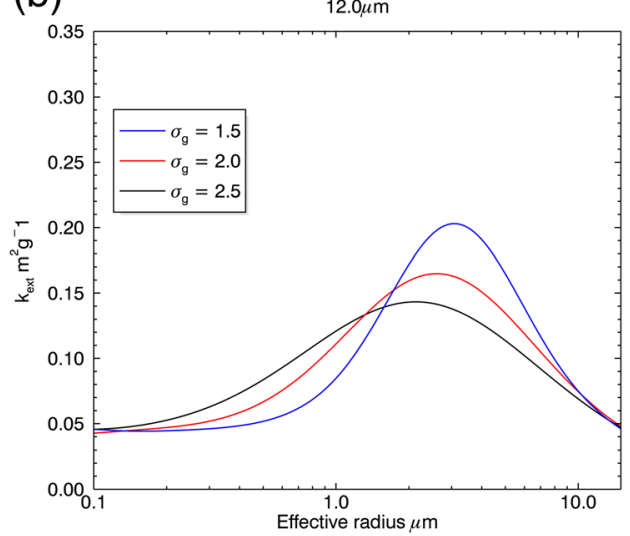

uncertainty in cloud top and surface temperature is suppressed where cloud altitude is retrieved and surface temperature is estimated on a pixel-by-pixel basis (e.g. Francis et al. 2012; Pavolonis et al. 2013).

\section{Implications of uncertainty in mass loading retrievals}

Contamination level is the unit on which the European airspace flight safety warnings are based (European Aviation Safety Agency 2013). The areas of low, medium and high contamination are defined by mass per unit volume of $0.2<$ $m \leq 2 \mathrm{mg} \mathrm{m}^{-3}, 2<m<4 \mathrm{mg} \mathrm{m}^{-3}$ and $m \geq 4 \mathrm{mg} \mathrm{m}^{-3}$, respectively. The typical depths of the Eyjafjallajökull volcanic ash cloud were measured to be between 0.5 and $1.3 \mathrm{~km}$, with an average typical depth of $1 \mathrm{~km}$ (Marenco et al. 2011). As only two-dimensional mass column loadings are retrievable using passive infrared satellites, the assumption of cloud depth, combined with the large uncertainty associated with assumptions made during retrieval, leads to a combined uncertainty larger than which could be used to reliably classify airspace contamination levels.

\section{Reasons for retrieval uncertainties from size distribution}

The PSD of particles, in terms of a change in spread, is known to affect single scattering properties of atmospheric aerosols (Jennings et al. 1979; Bohren and Huffman 1983). However, variance in spread of volcanic ash PSDs is an area of uncertainty that has generally not been quantified in current methods of retrieval. The cause of uncertainty can be clearly seen in Fig. 5 where the mass extinction coefficient, $k_{\text {ext }}$, is shown as a function of effective radius for a lognormal distribution with $\sigma_{\mathrm{g}}=1.5,2.0$ and 2.5 at 10.8 and $12.0 \mu \mathrm{m}$. Because different single scattering properties per unit mass would be observed for different values of $\sigma_{\mathrm{g}}$, an incorrect assumption of $\sigma_{\mathrm{g}}$ would lead to an incorrect quantification of mass and effective radii. This is logical considering Eq. (8), where $\tilde{Q}_{\text {ext }}$ itself is a function of size distribution, $n(r)$.

If a change in particle size spread is neglected, it is then assumed that the effective radius of particles in a distribution is representative of the mean radius of extinction. Such a situation, where the effective radius of a distribution of particles is representative of the scattering radius of particles, as opposed to the extinction radius, is discussed by Hansen and Travis (1974). This generally occurs when the size of the scattering particle is much larger than the incident wavelength of light.

\section{Conclusion}

It has been shown that because different parameters can be chosen to evaluate an ash cloud, even from a wellcharacterised eruption, there remain large uncertainties in estimates of the mass loading of a volcanic ash cloud made using a two-channel look-up table. With many of the parameters' values determined post-eruption, any real-time remote sensing is likely to involve much larger uncertainties than those presented in this paper. The effect of an uncertain assumption about the spread of a size distribution, even when the form of the PSD has been verified through in situ observation, is shown to cause the largest associated uncertainty for the Eyjafjallajökull ash cloud on 6 and 13 May 2010. This has implications for all passive infrared retrieval schemes that assume a constant spread of PSD. Little information is available for airborne ash PSDs, and information from any single event may be unavailable or inconsistent. It is not known how the PSD within an airborne ash cloud differs either spatially or temporally. Further information about volcanic ash PSDs, in particular, the form of size distribution curves and extremes of distribution spread likely to be encountered, is needed in order to improve remote sensing and dispersion modelling techniques. Its acquisition requires in situ sampling. 
Acknowledgments The work was funded under grant number $\mathrm{Ne} /$ K007912/1, a NERC Met Office CASE studentship. ECMWF and EUMETSAT are acknowledged for allowing access to the Global Reanalysis data set and SEVIRI images, respectively. The authors would like to thank Fred Prata and two anonymous reviewers for their helpful suggestions of improving the manuscript. The authors would also like to thank Kate Wilkins and Shona Mackie for their helpful input.

Open Access This article is distributed under the terms of the Creative Commons Attribution 4.0 International License (http:// creativecommons.org/licenses/by/4.0/), which permits unrestricted use, distribution, and reproduction in any medium, provided you give appropriate credit to the original author(s) and the source, provide a link to the Creative Commons license, and indicate if changes were made.

\section{References}

Beckett F, Witham C, Hort M, Stevenson J, Bonadonna C, Millington S (2014) The sensitivity of NAME forecasts of the transport of volcanic ash clouds to the physical characteristics assigned to the particles

Bohren CF, Huffman DR (1983) Absorption and scattering of light by small particles. absorption and scattering of light by small particles. Wiley

Bonadonna C, Phillips J (2003) Sedimentation from strong volcanic plumes. J Geophys Res 108:1-28. doi:10.1029/2002JB002034

Bonadonna C, Genco R, Gouhier M, Pistolesi M, Cioni R, Alfano F, Hoskuldsson A, Ripepe M (2011) Tephra sedimentation during the 2010 Eyjafjallajökull eruption (Iceland) from deposit, radar, and satellite observations. J Geophys Res Solid Earth. doi:10.1029/ 2011JB008462

Bukowiecki N, Zieger P, Weingartner E et al (2011) Ground-based and airborne in-situ measurements of the Eyjafjallajökull volcanic aerosol plume in Switzerland in spring 2010. Atmos Chem Phys 11: 10011-10030. doi:10.5194/acp-11-10011-2011

Carn SA, Froyd KD, Anderson BE (2011) In situ measurements of tropospheric volcanic plumes in Ecuador and Colombia during TC4. J Geophys Res Atmos 116:1-24. doi:10.1029/2010JD014718

Centre LVAA (2014) London Volcanic Ash Advisory Centre (VAAC). http://www.metoffice.gov.uk/aviation/vaac/

Chuan RL, Woods DC, McCormick MP (1981) Characterization of aerosols from eruptions of Mount St. Helens. Science (80-) 211:830 832. doi: $10.1126 /$ science. 211.4484 .830

Chuan RL, Palais J, Rose WI, Kyle PR (1986) Fluxes, sizes, morphology and compositions of particles in the Mt. Erebus Volcanic Plume, December 1983. J Atmos Chem 4:467-477. doi:10.1007/ BF00053846

Clarisse L, Hurtmans D, Prata AJ, Karagulian F, Clerbaux C, De Mazière M, Coheur P-F (2010) Retrieving radius, concentration, optical depth, and mass of different types of aerosols from high-resolution infrared nadir spectra. Appl Opt 49:3713-3722. doi:10.1364/AO. 49.003713

Clerbaux C, Boynard A, Clarisse L, George M, Herbin H, Hurtmans D, Pommier M (2009) Monitoring of atmospheric composition using the thermal infrared IASI/MetOp sounder. Atmos Chem Phys 9: 6041-6054. doi:10.5194/acp-9-6041-2009

Corradini S, Spinetti C, Carboni E, Tirelli C, Buongiorno MF, Pugnahi S, Gangale G (2008) Mt. Etna tropospheric ash retrieval and sensitivity analysis using moderate resolution imaging spectroradiometer measurements. J Appl Remote Sens 2:023550. doi:10.1117/1.3046674

Dartevelle S, Ernst GGJ, Stix J, Bernard A (2002) Origin of the Mount Pinatubo climactic eruption cloud: implications for volcanic hazards and atmospheric impacts. Geology 30:663. doi:10.1130/00917613(2002)030<0663:OOTMPC $>2.0 . \mathrm{CO} ; 2$
Dee DP, Uppala SM, Simmons AJ (2011) The ERA-Interim reanalysis: configuration and performance of the data assimilation system. Q J R Meteorol Soc 137:553-597. doi:10.1002/qj.828

European Aviation Safety Agency (2013) EASA Safety Information Bulletin: flight in airspace with contamination of volcanic ash. Cologne

Farlow NH, Oberbeck VR, Snetsinger KG, Ferry GV, Polkowski G, Hayes DM (1981) Size distributions and mineralogy of ash particles in the stratosphere from eruptions of Mount St. Helens. Science (80) 211:832-834. doi:10.1126/science.211.4484.832

Francis PN, Cooke MC, Saunders RW (2012) Retrieval of physical properties of volcanic ash using Meteosat: a case study from the 2010 Eyjafjallajökull eruption. J Geophys Res Atmos. doi:10.1029/ 2011JD016788

Gooding JL, Clanton US, Gabel EM, Warren JL (1983) El Chichón volcanic ash in the stratosphere: particle abundances and size distributions after the 1982 eruption. Geophys Res Lett 10:1033-1036. doi:10.1029/GL010i011p01033

Gudmundsson MT, Thordarson T, Höskuldsson Á et al (2012) Ash generation and distribution from the April-May 2010 eruption of Eyjafjallajökull, Iceland. Sci Rep 2:572. doi:10.1038/srep00572

Hansen JE, Travis LD (1974) Light scattering in planetary atmospheres. Space Sci Rev 16:527-610. doi:10.1007/BF00168069

Harrison RG, Nicoll KA, Ulanowski Z, Mather TA (2010) Self-charging of the Eyjafjallajökull volcanic ash plume. doi: 10.1088/1748-9326/ $5 / 2 / 024004$

Hobbs PV, Radke LF, Stith JL (1977) Eruptions of the St. Augustine Volcano: airborne measurements and observations. Science (80-) 195:871-873. doi:10.1126/science.195.4281.871

Hobbs PV, Radke LF, Eltgroth MW, Hegg DA (1981) Airborne studies of the emissions from the volcanic eruptions of Mount St. Helens. Science (80-) 211:816-818. doi:10.1126/science.211.4484.816

Hobbs V, Tuel P, Hegg A, Radke LF, Eltgroth MW (1982) Particles and gases in the emissions from the 1980-1981 volcanic eruptions of Mt. St Helens J Geophys Res Ocean 87:11062-11086. doi:10.1029/ JC087iC13p11062

Hobbs V, Radke F, Lyons H, Ferek J, Coffman DJ, Salmon K (1991) Airborne measurements of particle and gas emissions from the 1990 volcanic eruptions of Mount Redoubt. J Geophys Res Atmos 96: 18735-18752. doi:10.1029/91JD01635

International Air Transport Association (2010) The impact of Eyjafjallajökull's volcanic ash plume. Montreal

Jennings SG, Pinnick RG, Gillespie JB (1979) Relation between absorption coefficient and imaginary index of atmospheric aerosol constituents. Appl Opt 18:1368-1371. doi:10.1364/AO.18.001368

Johnson B, Turnbull K, Brown P, et al. (2012) In situ observations of volcanic ash clouds from the FAAM aircraft during the eruption of Eyjafjallajökull in 2010. J Geophys Res D Atmos 117:n/a-n/a. doi: 10.1029/2011JD016760

Knollenberg RG, Huffman D (1983) Measurements of the aerosol size distributions in the El Chichon cloud. Geophys Res Lett 10:10251028. doi:10.1029/GL010i011p01025

Mackie S, Millington S, Watson IM (2014) How assumed composition affects the interpretation of satellite observations of volcanic ash. Meteorol Appl 21:20-29. doi:10.1002/met.1445

Marenco F, Johnson B, Turnbull K, Newman S, Haywood J, Webster H, Ricketts H (2011) Airborne lidar observations of the 2010 Eyjafjallajökull volcanic ash plume. J Geophys Res Atmos. doi: 10.1029/2011JD016396

Mastin LG, Guffanti M, Servranckx R et al (2009) A multidisciplinary effort to assign realistic source parameters to models of volcanic ashcloud transport and dispersion during eruptions. J Volcanol Geotherm Res 186:10-21. doi:10.1016/j.jvolgeores.2009.01.008

Miller TP, Casadevall TJ (2000) Volcanic ash hazards to aviation. In: Sigurdsson H (ed) Encyclopedia of volcanoes. Academic, San Diego, pp 915-930 
Millington SC, Saunders RW, Francis PN, Webster HN (2012) Simulated volcanic ash imagery: a method to compare NAME ash concentration forecasts with SEVIRI imagery for the Eyjafjallajökull eruption in 2010. J Geophys Res Atmos 117:n/a-n/a. doi: 10.1029/ 2011JD016770

Mosca S, Graziani G, Klug W, Bellasio R, Bianconi R (1998) A statistical methodology for the evaluation of long-range dispersion models: an application to the ETEX exercise. Atmos Environ 32:4307-4324. doi: 10.1016/S1352-2310(98)00179-4

Mossop S (1964) Volcanic dust collected at an altitude of $20 \mathrm{KM}$. Nature 203:827-827. doi:10.1038/203824a0

Pavolonis MJ (2010) Advances in extracting cloud composition information from spaceborne infrared radiances - a robust alternative to brightness temperatures. Part I: theory. J Appl Meteorol Climatol 49:1992-2012. doi:10.1175/2010JAMC2433.1

Pavolonis MJ, Heidinger AK, Sieglaff J (2013) Automated retrievals of volcanic ash and dust cloud properties from upwelling infrared measurements. J Geophys Res Atmos 118:1436-1458. doi:10.1002/ jgrd.50173

Pelley R, Cooke M, Manning A, Thomson D, Witham C, Hort M (in preparation) Inversion technique for estimating volcanic ash source parameters in near real time using satellite retrievals. Forecasting Research Technical Note xxxx. Met Office

Pollack JB, Toon OB, Khare BN (1973) Optical properties of some rocks and glasses. Icarus 19:372-389. doi:10.1016/0019-1035(73)90115-2

Prata AJ (1989a) Observations of volcanic ash clouds in the 10-12 $\mu \mathrm{m}$ window using AVHRR/2 data. Int J Remote Sens 10:751-761. doi: $10.1080 / 01431168908903916$

Prata AJ (1989b) Infrared radiative transfer calculations for volcanic ash clouds. Geophys Res Lett 16:1293-1296. doi:10.1029/ GL016i011p01293

Prata AJ, Grant IF (2001a) Retrieval of microphysical and morphological properties of volcanic ash plumes from satellite data: application to Mt Ruapehu, New Zealand. Q J R Meteorol Soc 127:2153-2179. doi:10.1256/smsqj.57614

Prata AJ, Grant IF (2001b) Determination of mass loadings and plume heights of volcanic ash clouds from satellite data. CSIRO Atmos Res Tech Pap 48:1-41

Prata AJ, Prata AT (2012) Eyjafjallajökull volcanic ash concentrations determined using Spin Enhanced Visible and Infrared Imager measurements. J Geophys Res D Atmos. doi:10.1029/2011JD016800

Prata F, Bluth G, Rose B, Schneider D, Tupper A (2001) Comments on "failures in detecting volcanic ash from a satellite-based technique". Remote Sens Environ 78:341-346. doi:10.1016/S0034-4257(01) 00231-0
Rose WI, Durant AJ (2009) Fine ash content of explosive eruptions. J Volcanol Geotherm Res 186:32-39. doi:10.1016/j.jvolgeores.2009. 01.010

Rose WI, Chuan RL, Cadle RD, Woods DC (1980) Small particles in volcanic eruption clouds. Am J Sci 280:671-696. doi:10.2475/ajs. 280.8.671

Rose W, Chuan RL, Woods DC (1982) Small particles in plumes of Mount St Helens. J Geophys Res Ocean 87:4956-4962. doi:10. 1029/JC087iC07p04956

Rust AC, Cashman KV (2011) Permeability controls on expansion and size distributions of pyroclasts. J Geophys Res B Solid Earth. doi: 10.1029/2011JB008494

Schumann U, Weinzierl B, Reitebuch O et al (2011) Airborne observations of the Eyjafjalla volcano ash cloud over Europe during air space closure in April and May 2010. Atmos Chem Phys 11: 2245-2279. doi:10.5194/acp-11-2245-2011

Sherlock V (1999) ISEM-6: Infrared Surface Emissivity Model for RTTOV-6 for the EUMETSAT NWP SAF

Simpson J (2000) Failures in detecting volcanic ash from a satellite-based technique. Remote Sens Environ 72:191-217

Spinetti C, Barsotti S, Neri A, Buongiorno MF, Doumaz F, Nannipieri L (2013) Investigation of the complex dynamics and structure of the 2010 Eyjafjallajökull volcanic ash cloud using multispectral images and numerical simulations. J Geophys Res Atmos 118:4729-4747. doi:10.1002/jgrd.50328

Stevenson JA, Millington SC, Beckett FM, Swindles GT (2015) Big grains go far : reconciling tephrochronology with atmospheric measurements of volcanic ash. Atmos Meas Tech Discuss 65-120. doi: 10.5194/amtd-8-65-2015

Turnbull K, Johnson B, Marenco F (2012) A case study of observations of volcanic ash from the Eyjafjallajökull eruption: 1. In situ airborne observations. J Geophys Res D Atmos. doi:10.1029/2011JD016688

Volz FE (1973) Infrared optical constants of ammonium sulfate, sahara dust, volcanic pumice, and flyash. Appl Opt 12:564-568

Wen S, Rose WI (1994) Retrieval of sizes and total masses of particles in volcanic clouds using AVHRR bands 4 and 5. J Geophys Res Atmos 99:5421-5431. doi:10.1029/93JD03340

Winker DM, Vaughan MA, Omar A, Hu Y, Powell KA, Liu Z, Hunt WH, Young SA (2009) Overview of the CALIPSO mission and CALIOP data processing algorithms. J Atmos Ocean Technol 26:2310-2323. doi:10.1175/2009JTECHA1281.1

Woods DC, Chuan RL (1982) Fine particles in the soufriere eruption plume. Science (80-) 216:1118-1119. doi:10.1126/science.216. 4550.1118 